The Canadian Mineralogist

Vol. 39, pp. 73-83 (2001)

\title{
STRUCTURAL STATE OF K-FELDSPAR IN THE FELSIC VOLCANIC ROCKS AND RING PLUTON GRANITES OF THE BUTLER HILL CALDERA, ST. FRANCOIS MOUNTAINS, SOUTHEASTERN MISSOURI
}

\author{
THOMAS G. PLYMATE ${ }^{\S}$, JAMES D. KENDALLII, LISA M. SHEPARD ${ }^{\ddagger}$ AND KENNETH C. CLARK \\ Department of Geography, Geology, and Planning, Southwest Missouri State University, \\ Springfield, Missouri 65804-0089, U.S.A.
}

\begin{abstract}
The K-feldspar in all major rock units exposed in the Middle Proterozoic Butler Hill Caldera, St. Francois Mountains, southeastern Missouri, shows a high, but not maximum, degree of structural order. The structural state parameter $Z$ for phenocryst material from the felsic volcanic rock units averages 0.89 , with a standard deviation of 0.06 ( $Z$ would be 1 in fully ordered microcline). K-feldspar extracted from the matrix of these same samples yields an average $Z$ value of 0.86 , with a standard deviation of 0.07 . The $Z$ parameter for the K-feldspar in the ring pluton granites averages 0.87 , with a standard deviation of 0.06 . The structural state of the K-feldspar in these ring pluton granites is virtually identical to that reported by our group for the Butler Hill - Breadtray Granite, the subvolcanic granite massif exposed in the center of the Butler Hill Caldera. There is no statistically significant variation of K-feldspar structural state with inferred structural elevation, present topographic elevation, or proximity to the Simms Mountain Fault. We interpret the homogeneity of the K-feldspar structural state throughout the Butler Hill Caldera complex, and especially the unexpectedly high degree of structural order in the volcanic K-feldspar, as evidence for a pervasive alteration event, which re-ordered the K-feldspar throughout the entire volcanic-plutonic complex. The most likely cause of the homogenization of the K-feldspar structural state is the late-stage alkaline magmatism inferred to have occurred throughout the St. Francois Mountains at approximately $1.36 \mathrm{Ga}$.
\end{abstract}

Keywords: K-feldspar, structural state, granite, rhyolite, Butler Hill Caldera, St. Francois Mountains, Missouri, Proterozoic, alteration.

\section{SOMMAIRE}

Le feldspath potassique présent dans chaque unité lithologique majeure de la caldeira de Butler Hill, dans les montagnes St. François, dans le sud-est du Missouri, d'âge protérozoïque moyen, fait preuve d'un degré d'ordre élevé, mais non maximum. Le paramètre structural $Z$ des phénocristaux des roches felsiques volcaniques, par exemple, est en moyenne 0.89, avec un écart-type de 0.06 (dans le microcline parfaitement ordonné, $Z$ est égal à 1 ). Le feldspath potassique dans la matrice de ces mêmes roches possède une valeur de $Z$ de 0.86 , avec un écart-type de 0.07 . Dans le cas des granites annulaires associés, le paramètre $Z$ du feldspath potassique est en moyenne 0.87, avec un écart-type de 0.06. Le degré d'ordre Al-Si du feldspath potassique dans ces granites annulaires est donc quasiment le même que dans le granite pour le pluton de Butler Hill - Breadtray, le granite subvolcanique affleurant dans le centre de la caldeira de Butler Hill. Du point de vue statistique, il n'y a aucune variation dans le degré d'ordre avec l'altitude structurale dans l'édifice volcanique, l'élévation topographique actuelle, ou la proximité à la faille de Simms Mountain. L'homogénéité dans le degré d'ordre du feldspath potassique de part et d'autre dans le complexe de Butler Hill, et particulièrement le degré d'ordre anormalement élevé du feldspath potassique dans les roches volcaniques, font penser qu'une altération hydrothermale très répandue a mené à un ré-équilibrage du feldspath potassique partout dans le complexe volcanique-plutonique. La cause probable de cette mise en ordre serait la mise en place tardive de roches ignées alcalines dans la région il y a environ 1.36 milliard d'années.

(Traduit par la Rédaction)

Mots-clés: feldspath potassique, degré d'ordre, granite, rhyolite, caldeira de Butler Hill, montagnes St. François, Missouri, protérozoïque, altération.

§ E-mail address: tgp438f@smsu.edu

II Present address: Marathon Oil Co., 909 E.S.E. Loop 323, Suite 300, Tyler, Texas 75713, U.S.A.

$¥ \quad$ Present name and address: Lisa Schwartz, Department of Chemistry, Indiana University, Bloomington, Indiana 47405, U.S.A. 


\section{INTRODUCTION}

The St. Francois Mountains, located approximately $120 \mathrm{~km}$ south-southwest of St. Louis, Missouri, provide the only significant surface exposures of the Mesoproterozoic Eastern Granite-Rhyolite Province of the Precambrian basement of the mid-continent region (Van Schmus et al. 1993). Over an area of approximately $900 \mathrm{~km}^{2}$, the Paleozoic sedimentary rocks have been eroded off the Ozark Dome, exposing a series of felsic volcanic rocks and epizonal granitic plutons (Kisvarsanyi 1990, Kisvarsanyi et al. 1981, Pratt et al. 1979). These Proterozoic rocks have been interpreted to be the remnants of two large, partially collapsed caldera structures, the Taum Sauk Caldera to the west and the Butler Hill Caldera to the east (Sides et al. 1981).

The Butler Hill Caldera (Fig. 1) exposes a sequence of layered felsic volcanic rocks, a large zoned granitic subvolcanic massif, and a series of ring plutons (Lowell 1991), all formed by magmatic activity at $1.47 \pm 0.03$ $\mathrm{Ga}$ (Van Schmus et al. 1996). The perimeter of the Butler Hill Caldera (which is truncated to the northeast by the Simms Mountain Fault) is dominated by layered rhyolitic ash-flow tuffs and related felsic volcanic rocks. Following the terminology of Pratt et al. (1979), these volcanic units include Quartz Latite (Ys), Grassy Mountain Ignimbrite (Yag), and Alkali Rhyolite (Yar). The center of the Butler Hill Caldera exposes the Butler Hill - Breadtray Granite (Ygh + Ygg), a large texturally, mineralogically, and chemically differentiated, highsilica granite body interpreted to have formed as a subvolcanic massif that crystallized beneath a cover of its own volcanic ejecta (Sides 1980). Forming an arcuate ring between the outcrop areas of the Butler Hill Breadtray Granite and the surrounding volcanic units are a series of smaller, lower-silica, amphibole-bearing

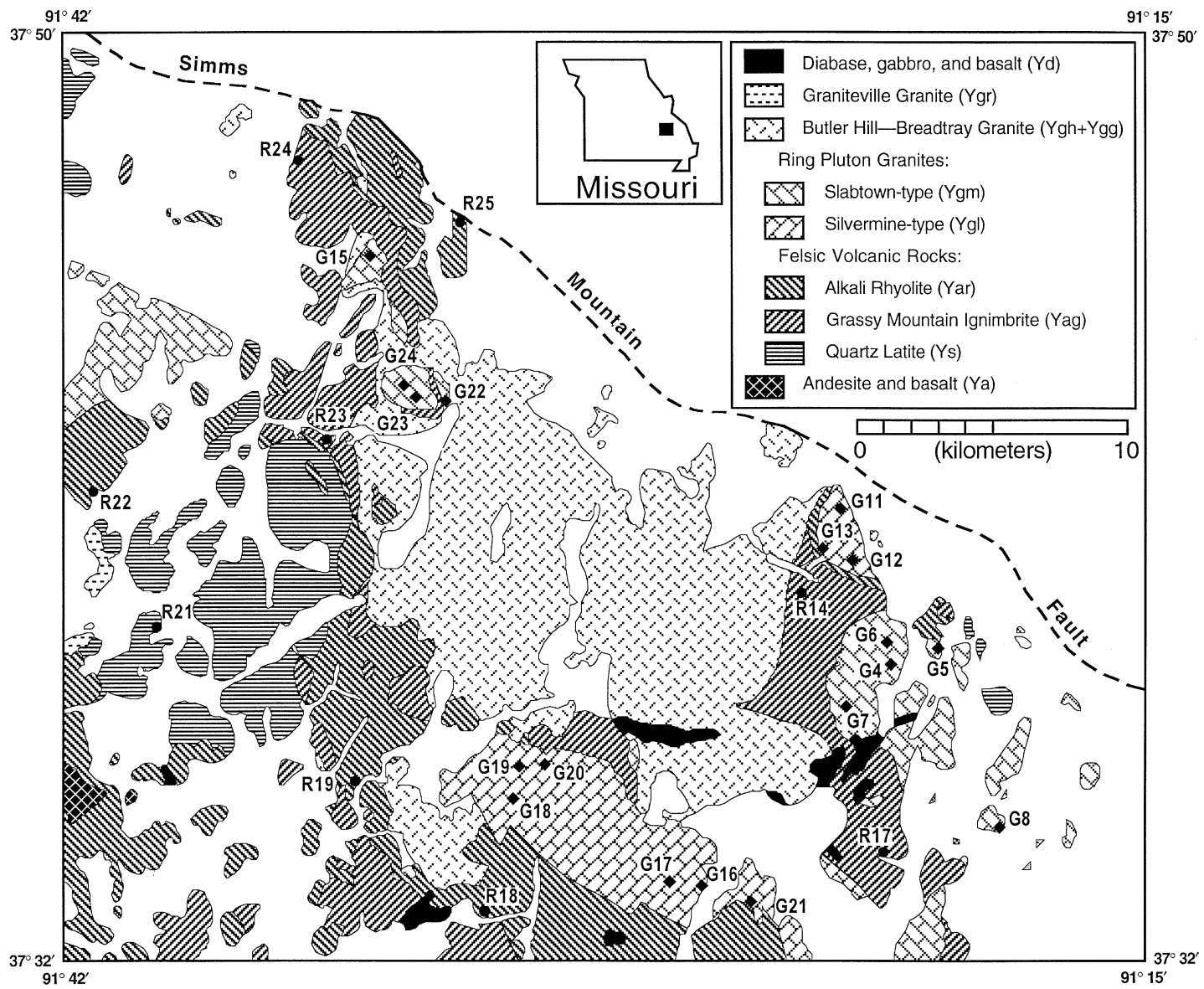

FIG. 1. Generalized geological map of the Proterozoic rocks exposed in the Butler Hill Caldera, eastern St. Francois Mountains, southeastern Missouri (after Pratt et al. 1979), showing sample locations for volcanic rocks $(\bullet)$ and ring pluton granites ( $\bullet$ ) used in this study. 
granitic plutons, interpreted to have been emplaced during collapse of the central portion of the caldera (Lowell 1991). Clockwise from the east (Fig. 1), these ring plutons include the Knoblick Granite (Ygl), Slabtown Granite (Ygm), Silvermine Granite (Ygl), and Stono Granite (Ygm) (Pratt et al. 1979).

On the basis of general field relationships among the various Proterozoic volcanic and plutonic units, Bickford et al. (1977) suggested that the exposed portion of the Butler Hill Caldera complex had been tilted to the west-southwest and beveled by erosion. Clendenin et al. (1989) attributed this tilting to movement along the Simms Mountain Fault, one of a series of northwest-striking transfer faults formed during Late Proterozoic - Early Cambrian rifting and subsequently reactivated during the Middle to Late Paleozoic uplift of the Ozark Dome. On the basis of variation in majorelement geochemistry, Sides (1980) inferred that the Butler Hill - Breadtray Granite has been tilted approximately $10^{\circ}$ in the $\mathrm{S} 68^{\circ} \mathrm{W}$ direction, exposing rocks that had crystallized at depths ranging from as great as $10 \mathrm{~km}$ along the northeastern edge of the exposure to as little as 1 to $2 \mathrm{~km}$ along the intrusive contact with the volcanic rocks to the southwest.

In an attempt to corroborate the inferred range of depth of crystallization for the exposed portions of the Butler Hill - Breadtray Granite, Plymate et al. (1992) determined the structural state of the K-feldspar in twenty-eight samples from that rock unit. Rather than finding a significant, systematic variation of K-feldspar structural state with inferred depth of crystallization, however, they found the K-feldspar in the Butler Hill Breadtray Granite to be uniformly highly ordered. They interpreted this uniformly high degree of order as evidence that a pervasive reheating or deuteric-hydrothermal event had reset the structural state of the K-feldspar within the Butler Hill - Breadtray Granite subsequent to its crystallization. The purpose of the present work is to extend the study of Plymate et al. (1992) to include the volcanic rocks and ring pluton granites exposed around the perimeter of the Butler Hill Caldera, to further determine the extent and timing of the process(es) or event(s) responsible for resetting the structural state of K-feldspar.

\section{ExPerimental Procedure}

We have determined the structural state of the Kfeldspar in twenty-eight samples, ten from the volcanic rock units and eighteen from the ring pluton granites (Fig. 1, Tables 1, 2). For the volcanic samples, we analyzed K-feldspar from the phenocrysts and the matrix separately. In collecting the samples, we took care to avoid dikes, veins, and other obvious contamination, but the exposure in some areas was not sufficiently good to yield completely fresh samples.

Samples were slabbed, and visible weathering rinds or xenoliths were removed. These slabs were then crushed, and $\mathrm{K}$-feldspar was concentrated by centrifuge, using acetylene tetrabromide diluted to the desired density with dimethyl formamide. For granite samples, the first centrifugation was performed using the -120 mesh fraction and a fluid density of $2.585 \mathrm{~g} \mathrm{~cm}^{-3}$. The K-feldspar concentrate yielded by this step was filtered, rinsed in acetone, dried, and ground to a fine powder in a tungsten carbide ball mill. The K-feldspar in the -325 mesh fraction of this powder was further purified by two additional centrifugations in a fluid of density $2.580 \mathrm{~g}$ $\mathrm{cm}^{-3}$.

For volcanic samples, additional steps were necessary between crushing and the first centrifugation to separate phenocryst material from matrix material. We suspended the 18-35 mesh fraction in heavy liquid in $1000 \mathrm{~mL}$ graduated cylinders and adjusted the density of the fluid until approximately $5 \%$ of these coarse-sandsized chips floated. We removed, filtered, rinsed, and dried this light fraction and confirmed with a binocular microscope that it consisted almost entirely of chips of K-feldspar phenocrysts. We next adjusted the density of the fluid in the graduated cylinder until approximately $50 \%$ of the remaining chips floated; we removed and discarded these intermediate-density chips. We filtered, rinsed, and dried the chips that had remained in the bottom of the graduated cylinder and confirmed with the binocular microscope that this heavy fraction consisted almost entirely of chips of matrix material. Each resulting phenocryst and matrix separate was ground to a fine powder in the tungsten carbide ball mill, and the K-feldspar in the -325 mesh fraction was purified by two centrifugations in fluid of density $2.580 \mathrm{~g} \mathrm{~cm}^{-3}$.

$\mathrm{K}$-feldspar concentrates were analyzed by X-ray powder diffraction $\left(\mathrm{Cu} K \alpha\right.$ radiation) from $18^{\circ}$ to $54^{\circ}$ $2 \theta$ at a scan rate of $0.10^{\circ} /$ minute using a fully automated Scintag XDS-2000 diffraction system with a $\theta-\theta$ goniometer and a germanium solid-state detector. The alignment of the goniometer was calibrated using finely powdered quartz (Fisher Reagent Grade $\mathrm{SiO}_{2}$ ) as an external standard.

A preliminary estimate of the structural state of the $\mathrm{K}$-feldspar in each sample was determined from the (060) and (204) peaks (Wright 1968), and the rest of the $\mathrm{K}$-feldspar peaks were indexed according to Appendix A11 of Ribbe (1983). Despite our efforts to purify the $\mathrm{K}$-feldspar, diffraction profiles for most samples were found to contain one or more peaks from quartz or albite. Therefore, lattice-parameter refinements of K-feldspar were based on the following fourteen singlet $\mathrm{K}$-feldspar peaks, which are free of any potential interference from peaks of quartz or albite: (201), (111),

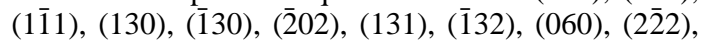

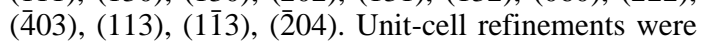
performed according to the procedure of Appleman \& Evans (1973). None of our thirty-five K-feldspar unitcell refinements indicated more than $10 \%$ lattice strain according to the procedure of Kroll \& Ribbe (1987). 
To verify the accuracy of our experimental system and techniques, we analyzed a sample of standard reference microcline (Waldbaum $\mathrm{D}+\mathrm{E}$ ). The results of this analysis are listed as the next-to-last line on Tables 1 and 2 and plotted with the $\nabla$ symbol on Figures $2 \mathrm{~B}$ and 3B. Within our experimental precision, this sample has a completely ordered maximum microcline structure.

\section{RESULTS}

Table 1 lists the results of our lattice-parameter refinements for the $\mathrm{K}$-feldspar in the felsic volcanic rocks and ring pluton granites of the Butler Hill Caldera. The uncertainties listed in Table 1 are the average standard errors for each parameter generated in the unit-cell re- finement regressions. Each value in this table is listed with one digit beyond the first uncertain digit so that these data can be used in subsequent calculations without the introduction of round-off error (Bevington 1969, Lyon 1970). Table 2 lists structural state parameters calculated from the refined unit-cell parameters for each K-feldspar sample. The uncertainties listed in Table 2 were determined by propagating the experimental uncertainties from Table 1 through the defining equations for each of the calculated structural parameters according to the techniques discussed by Bevington (1969) and Meyer (1975).

The K-feldspar in all samples analyzed in this study shows a high, but not maximum, degree of structural order. On standard plots of the $b$ versus $c$ and $\alpha^{*}$ versus

TABLE 1. MEASURED UNIT-CELL PARAMETERS OF K-FELDSPAR

IN THE ST. FRANCOIS MOUNTAINS SUITE, SOUTHEASTERN MISSOURI

\begin{tabular}{|c|c|c|c|c|c|c|c|c|c|c|}
\hline & Sample & $\begin{array}{l}\text { Northing }{ }^{\dagger} \\
\text { (meters) }\end{array}$ & $\begin{array}{l}\text { Easting } \\
\text { (meters) }\end{array}$ & $\begin{array}{l}\text { Elevation } \\
\text { (meters) }\end{array}$ & $a$ & $\begin{array}{c}b \\
\text { (Ångströms) }\end{array}$ & $c$ & $\alpha$ & $\begin{array}{c}\beta \\
\text { (degrees) }\end{array}$ & $\mathrm{r}$ \\
\hline $\begin{array}{l}\text { Yag } \\
\text { Phenocrysts }\end{array}$ & $\begin{array}{l}\text { R14P } \\
\text { R17P } \\
\text { R23P } \\
\text { R24P }\end{array}$ & $\begin{array}{l}4170217 \\
4160716 \\
4175843 \\
4186265\end{array}$ & $\begin{array}{l}730120 \\
733012 \\
712313 \\
710976\end{array}$ & $\begin{array}{l}296 \\
265 \\
323 \\
290\end{array}$ & $\begin{array}{l}8.5915 \\
8.5828 \\
8.5858 \\
8.5947\end{array}$ & $\begin{array}{l}12.9725 \\
12.9694 \\
12.9674 \\
12.9725\end{array}$ & $\begin{array}{l}7.2140 \\
7.2180 \\
7.2177 \\
7.2229\end{array}$ & $\begin{array}{l}90.152 \\
90.546 \\
90.432 \\
90.380\end{array}$ & $\begin{array}{l}116.087 \\
115.900 \\
115.910 \\
116.005\end{array}$ & $\begin{array}{l}88.420 \\
87.981 \\
88.216 \\
88.105\end{array}$ \\
\hline $\begin{array}{l}\text { Yag } \\
\text { Matrix }\end{array}$ & $\begin{array}{l}\text { R14M } \\
\text { R17M } \\
\text { R23M } \\
\text { R24M }\end{array}$ & $\begin{array}{l}-\ldots \\
4170217 \\
4160716 \\
4175843 \\
4186265\end{array}$ & $\begin{array}{l}-\cdots \\
730120 \\
733012 \\
712313 \\
710976\end{array}$ & $\begin{array}{l}296 \\
265 \\
323 \\
290\end{array}$ & $\begin{array}{l}8.5863 \\
8.5845 \\
8.5883 \\
8.5898\end{array}$ & $\begin{array}{l}12.9673 \\
12.9634 \\
12.9637 \\
12.9684\end{array}$ & $\begin{array}{l}-\cdots \\
7.2142 \\
7.2230 \\
7.2149 \\
7.2206\end{array}$ & $\begin{array}{l}-\cdots \\
90.277 \\
90.515 \\
90.245 \\
90.422\end{array}$ & $\begin{array}{l}115.919 \\
116.017 \\
116.030 \\
115.982\end{array}$ & $\begin{array}{l}---- \\
88.514 \\
87.945 \\
88.510 \\
88.197\end{array}$ \\
\hline $\begin{array}{l}\text { Yar } \\
\text { Phenocrysts }\end{array}$ & $\begin{array}{l}\text { R18P } \\
\text { R19P } \\
\text { R22P } \\
\text { R25P }\end{array}$ & $\begin{array}{l}4158188 \\
4162887 \\
4172723 \\
4184159\end{array}$ & $\begin{array}{l}718827 \\
713880 \\
703627 \\
717108\end{array}$ & $\begin{array}{l}265 \\
256 \\
338 \\
338\end{array}$ & $\begin{array}{l}8.6014 \\
8.5806 \\
8.5926 \\
8.5964\end{array}$ & $\begin{array}{l}12.9762 \\
12.9681 \\
12.9690 \\
12.9805\end{array}$ & $\begin{array}{l}7.2190 \\
7.2194 \\
7.2098 \\
7.2143\end{array}$ & $\begin{array}{l}90.100 \\
90.388 \\
90.095 \\
90.280\end{array}$ & $\begin{array}{l}116.038 \\
116.097 \\
115.835 \\
115.988\end{array}$ & $\begin{array}{l}88.569 \\
88.233 \\
88.440 \\
88.524\end{array}$ \\
\hline $\begin{array}{l}\text { Yar } \\
\text { Matrix }\end{array}$ & $\begin{array}{l}\text { R18M } \\
\text { R19M } \\
\text { R25M }\end{array}$ & $\begin{array}{l}4158188 \\
4162887 \\
4184159\end{array}$ & $\begin{array}{l}-\ldots \ldots \\
718827 \\
713880 \\
717108\end{array}$ & $\begin{array}{l}\cdots-\cdots \\
265 \\
256 \\
338\end{array}$ & $\begin{array}{l}8.6042 \\
8.6035 \\
8.5926\end{array}$ & $\begin{array}{l}12.9760 \\
12.9731 \\
12.9706\end{array}$ & $\begin{array}{l}7.2049 \\
7.2174 \\
7.2084\end{array}$ & $\begin{array}{l}90.050 \\
90.198 \\
90.127\end{array}$ & $\begin{array}{l}115.847 \\
115.940 \\
115.986\end{array}$ & $\begin{array}{l}89.349 \\
88.716 \\
88.788\end{array}$ \\
\hline $\begin{array}{l}\text { Ys } \\
\text { Matrix }\end{array}$ & R15M & $\begin{array}{l}4149060 \\
4168571\end{array}$ & $\begin{array}{l}\ldots \\
732807 \\
706277\end{array}$ & $\begin{array}{l}\cdots \\
354 \\
357\end{array}$ & $\begin{array}{l}8.5902 \\
8.5988\end{array}$ & & $\begin{array}{l}-\ldots . .- \\
7.2136 \\
7.2192\end{array}$ & $\begin{array}{l}90.329 \\
90.407\end{array}$ & $\begin{array}{l}\ldots \\
115.844 \\
115.979\end{array}$ & $\begin{array}{l}\ldots . . \\
88.660 \\
88.179\end{array}$ \\
\hline $\begin{array}{l}\text { Ygm - } \\
\text { Slabtown Pluton }\end{array}$ & $\begin{array}{l}- \\
\text { G4 } \\
\text { G5 } \\
\text { G6 } \\
\text { G7 } \\
\text { G8 }\end{array}$ & $\begin{array}{l}- \\
4167639 \\
4168561 \\
4168622 \\
4166053 \\
4162024\end{array}$ & $\begin{array}{l}- \\
733282 \\
734957 \\
733096 \\
732084 \\
737639\end{array}$ & $\begin{array}{l}268 \\
277 \\
256 \\
311 \\
226\end{array}$ & $\begin{array}{l}8.5845 \\
8.5785 \\
8.5942 \\
8.5822 \\
8.5862\end{array}$ & $\begin{array}{l}12.9725 \\
12.9704 \\
12.9657 \\
12.9653 \\
12.9729\end{array}$ & $\begin{array}{l}-.2156 \\
7.2198 \\
7.2173 \\
7.2158 \\
7.2184\end{array}$ & $\begin{array}{l}-\ldots .370 \\
90.479 \\
90.406 \\
90.519 \\
90.694\end{array}$ & $\begin{array}{l}116.039 \\
116.065 \\
115.981 \\
115.907 \\
115.948\end{array}$ & $\begin{array}{l}-.-. \\
88.241 \\
88.121 \\
88.141 \\
88.202 \\
88.010\end{array}$ \\
\hline $\begin{array}{l}\text { Ygm - } \\
\text { Stono Mtn. Pluton }\end{array}$ & $\begin{array}{l}\text { G15 } \\
\text { G22 } \\
\text { G23 } \\
\text { G24 }\end{array}$ & $\begin{array}{l}4182253 \\
4177181 \\
4176422 \\
4177549\end{array}$ & $\begin{array}{l}713771 \\
715904 \\
716398 \\
715554\end{array}$ & $\begin{array}{l}369 \\
497 \\
390 \\
427\end{array}$ & $\begin{array}{l}- \\
8.5708 \\
8.5978 \\
8.5970 \\
8.5981\end{array}$ & $\begin{array}{l}12.9621 \\
12.9830 \\
12.9760 \\
12.9768\end{array}$ & $\begin{array}{l}-\cdot-\cdot- \\
7.2169 \\
7.2212 \\
7.2201 \\
7.2214\end{array}$ & $\begin{array}{l}- \\
90.585 \\
90.471 \\
90.366 \\
90.453\end{array}$ & $\begin{array}{l}116.036 \\
116.066 \\
116.022 \\
116.024\end{array}$ & $\begin{array}{l}---- \\
87.980 \\
88.030 \\
88.041 \\
88.068\end{array}$ \\
\hline $\begin{array}{l}\text { Ygl- } \\
\text { Silvermine Pluton }\end{array}$ & $\begin{array}{l}\text { G16 } \\
\text { G17 } \\
\text { G18 } \\
\text { G19 } \\
\text { G20 } \\
\text { G21 }\end{array}$ & $\begin{array}{l}4159333 \\
4159301 \\
4162643 \\
4163988 \\
4163675 \\
4159053\end{array}$ & $\begin{array}{l}- \\
726410 \\
725306 \\
719916 \\
720060 \\
720952 \\
728337\end{array}$ & $\begin{array}{l}- \\
189 \\
259 \\
223 \\
244 \\
219 \\
251\end{array}$ & $\begin{array}{l}8.5868 \\
8.5885 \\
8.5974 \\
8.5901 \\
8.5889 \\
8.6009\end{array}$ & $\begin{array}{l}12.9679 \\
12.9701 \\
12.9715 \\
12.9731 \\
12.9638 \\
12.9730\end{array}$ & $\begin{array}{l}-\cdot-\cdot- \\
7.2157 \\
7.2172 \\
7.2166 \\
7.2171 \\
7.2190 \\
7.2128\end{array}$ & $\begin{array}{l}- \\
90.096 \\
90.389 \\
90.367 \\
90.406 \\
90.420 \\
90.542\end{array}$ & $\begin{array}{l}115.981 \\
116.058 \\
115.996 \\
115.978 \\
115.909 \\
115.994\end{array}$ & $\begin{array}{l}--. \\
88.591 \\
88.053 \\
88.330 \\
88.101 \\
88.051 \\
88.126\end{array}$ \\
\hline & & - & $-\cdots$ & $\cdots$ & $-\cdots$ & $\cdots-\cdots$ & $-\cdots$ & $\ldots$ & $\cdots$ & $\cdots$ \\
\hline $\begin{array}{l}\text { Ygl - } \\
\text { Knob Lick Pluton }\end{array}$ & $\begin{array}{l}\text { G11 } \\
\text { G12 } \\
\text { G13 }\end{array}$ & $\begin{array}{l}4173458 \\
4172084 \\
4172102\end{array}$ & $\begin{array}{l}731398 \\
731790 \\
730663\end{array}$ & $\begin{array}{l}274 \\
285 \\
351\end{array}$ & $\begin{array}{l}8.5888 \\
8.5778 \\
8.5891\end{array}$ & $\begin{array}{l}12.9710 \\
12.9617 \\
12.9669\end{array}$ & $\begin{array}{l}7.2165 \\
7.2137 \\
7.2178\end{array}$ & $\begin{array}{l}90.073 \\
90.660 \\
90.474\end{array}$ & $\begin{array}{l}116.108 \\
115.968 \\
115.980\end{array}$ & $\begin{array}{l}88.403 \\
88.101 \\
88.089\end{array}$ \\
\hline \multicolumn{5}{|c|}{$\begin{array}{l}\text { Reference Microcline } \quad \text { Waldbaum } \mathrm{D}+\mathrm{E}^{\mathbb{\top}} \\
\text { Uncertainty }^{\ddagger}\end{array}$} & 8.5708 & (12.9579 & $\begin{array}{l}-\cdot- \\
7.2217 \\
-\cdots \\
0.0012\end{array}$ & (90.706 & (115.986 & 87.633 \\
\hline
\end{tabular}

$\dagger$ Universal Transverse Mercator Grid, Zone 15. " Kindly provided by R.F. Martin, McGill University.

$\ddagger$ Each uncertainty listed is the average of the standard errors for that parameter from the 36 unit-cell refinements. 
TABLE 2. CALCULATED STRUCTURAL PARAMETERS FOR K-FELDSPAR IN THE ST. FRANCOIS MOUNTAINS SUITE

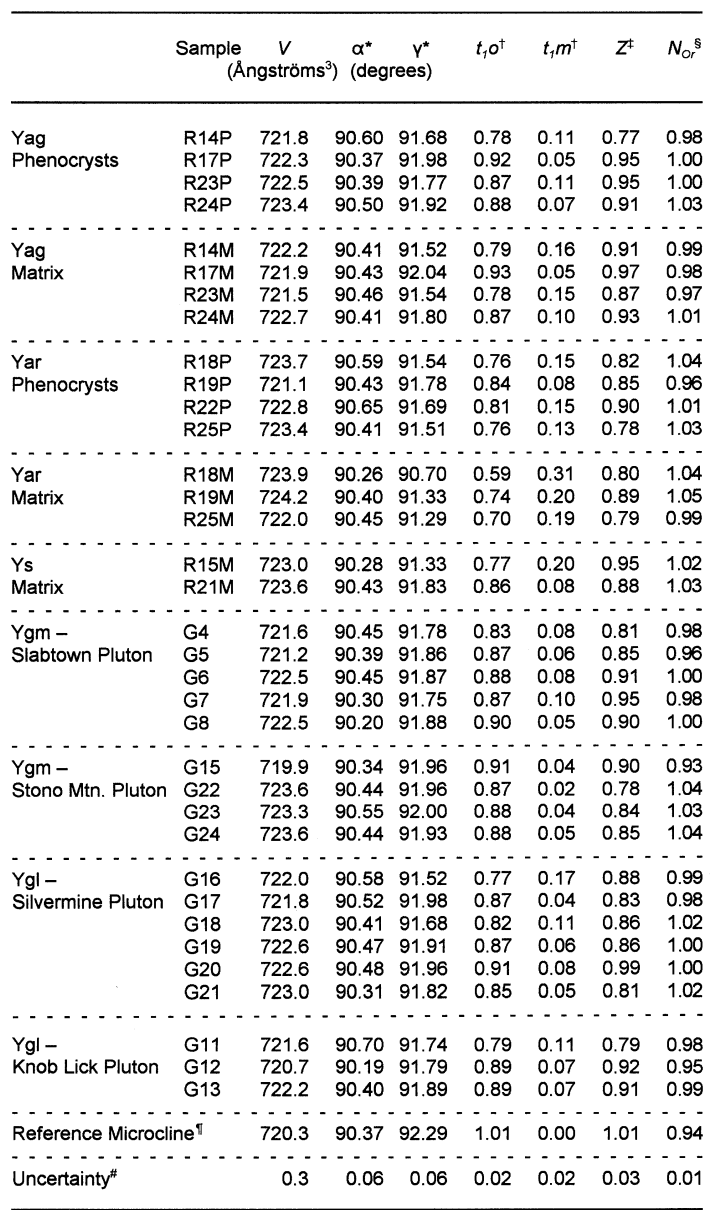

$\dagger$ Kroll \& Ribbe (1987), equations 6 and 12. ${ }^{\ddagger} Z \equiv t_{1} 0+t_{1} m-t_{2} \mathrm{O}-t_{2} m$, where $t_{2} \mathrm{O}$ $=t_{2} m=\left[1-\left(t_{1} 0+t_{1} m\right)\right] / 2$ (Kroll \& Ribbe 1983)

$\S$ Hovis (1986), equation 7 . "Waldbaum D+E microcline.

\# For each calculated parameter the experimental uncertainties from Table 1 were propagated through the defining equations as discussed by Bevington (1969) and Meyer (1975).

$\gamma^{*}$ lattice parameters (Wright \& Stewart 1968, Kroll \& Ribbe 1983), our samples cluster near, but are not coincident with, the low microcline end-point (Figs. 2, 3). The structural-state parameter $Z\left(\equiv t_{1} o+t_{1} m-t_{2} O-t_{2} m\right.$ where $t_{2} o=t_{2} m=\left[1-\left(t_{1} o+t_{1} m\right)\right) / 2$; Kroll \& Ribbe 1983] for all thirty-five analyses of the K-feldspar in these rocks varies from a low of 0.77 to a high of 0.99 with an average of 0.87 and a standard deviation of 0.06 .

The K-feldspar in the ring pluton granites is uniformly highly ordered. The $Z$ parameter for our eighteen analyses of these rocks averages 0.87 with a standard deviation of 0.06 . No significant difference in K-feldspar structural state was detected among the four ring pluton granite bodies sampled. The structural state
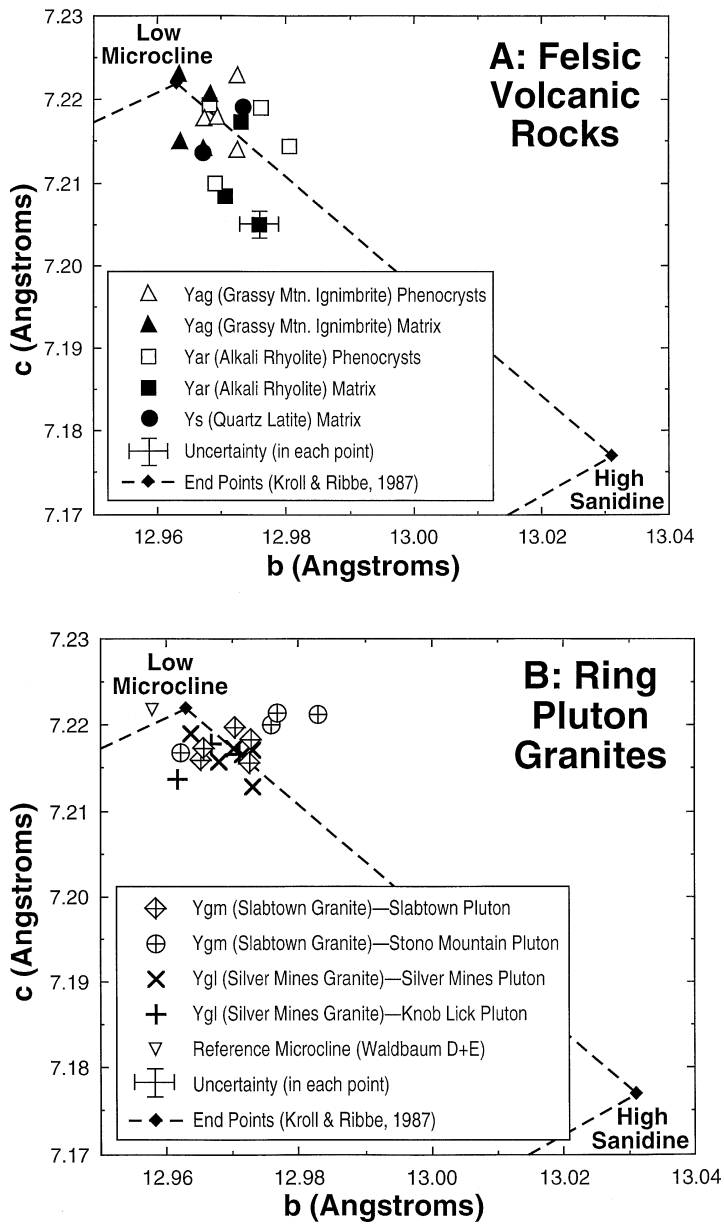

FIG. 2. Variation in K-feldspar structural state in the Butler Hill Caldera, as revealed by variation in the $b$ and $c$ cell parameters: (A) felsic volcanic rocks, and (B) ring pluton granites. The error bar included in the explanation indicates the experimental uncertainty in each data point.

of the K-feldspar in these ring pluton granites is virtually identical to that determined by Plymate et al. (1992) for twenty-eight samples of the Butler Hill - Breadtray Granite, the subvolcanic granite massif of the Butler Hill Caldera. [Note: Plymate et al. (1992) calculated $Z$ values according to the regression equations of Hovis (1986), whereas we have used the regression equations of Kroll \& Ribbe (1987), which appear to yield values more consistent with the $b-c$ and $\alpha^{*}-\gamma^{*}$ plots. Recalculation of the data of Plymate et al. (1992) according to the regression equations of Kroll \& Ribbe (1987) yields an average $Z$ of 0.91 with a standard deviation of 0.03 for the K-feldspar in the Butler Hill - Breadtray Granite.] 

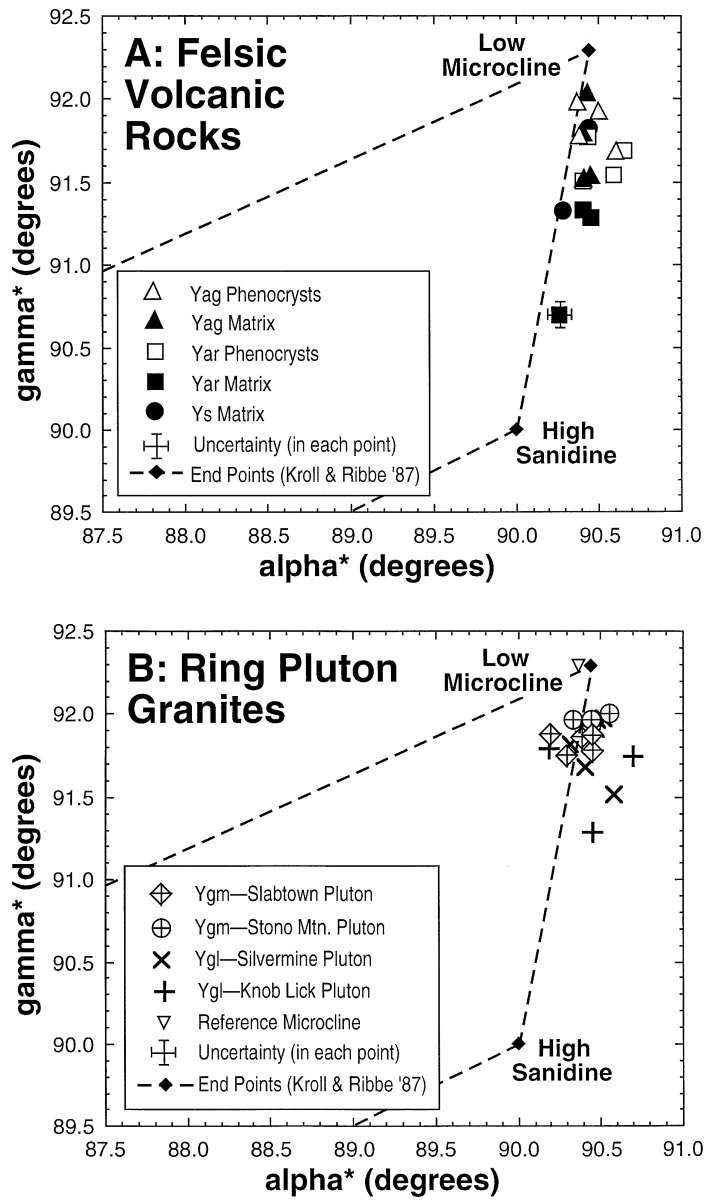

FIG. 3. Variation in K-feldspar structural state in the Butler Hill Caldera as revealed by variation in the angles $\alpha^{*}$ and $\gamma^{*}$ in reciprocal space: (A) felsic volcanic rocks, and (B) ring pluton granites. The error bar included in the explanation indicates the experimental uncertainty in each data point.

The K-feldspar in the felsic volcanic rocks also shows a high degree of structural order. Although the data for these rocks show a bit more scatter on the $b-c$ and $\alpha^{*}-\gamma^{*}$ plots than the data for the ring pluton granites, the values of the $Z$ parameter for these two groups of samples are statistically indistinguishable. Values of the $Z$ parameter for our nine samples of matrix material and our eight samples of phenocryst material from the felsic volcanic rocks are essentially identical: 0.86 mean with 0.07 standard deviation for the matrix and 0.89 mean with 0.06 standard deviation for the phenocrysts. On average, the K-feldspar in the Alkali Rhyolite (Yar) appears to be slightly less ordered than the K-feldspar in the Grassy Mountain Ignimbrite (Yag), but the small number of samples analyzed for each of these rock units precludes confirmation with statistical significance.

\section{DisCUSSION}

Plymate et al. (1992) showed that the structural state of the K-feldspar in the exposed portions of the Butler Hill - Breadtray Granite is virtually independent of the inferred depth of crystallization. The present study extends that conclusion to include all major igneous rock units exposed in the Butler Hill Caldera.

Figure 4A shows the K-feldspar structural state parameter $Z$ for our analyses, as well as those of Plymate et al. (1992) [recalculated using the regression equations of Kroll \& Ribbe (1987)], plotted versus elevation with respect to a surface dipping $10^{\circ}, \mathrm{S} 68^{\circ} \mathrm{W}$. This surface, arbitrarily anchored at sample site F4 of Plymate et al. (1992), represents a plane of constant major-element geochemistry within the main exposure of the Butler Hill - Breadtray Granite, and has therefore been inferred to represent a plane that was originally horizontal during the crystallization of this subvolcanic massif (Sides 1980). It is clear from Figure 4A that the structural state of the K-feldspar throughout the entire Butler Hill Caldera complex is highly ordered and very nearly homogeneous, and that there is no significant variation with inferred depth of crystallization. [Note that our data for the volcanic phenocrysts are omitted from this plot because we have no way of estimating the relative depth of crystallization for that material. For the same reason, the data for the two Butler Hill Granite samples which Plymate et al. (1992) collected northeast of the Simms Mountain Fault also have been omitted.] A linear regression of $Z$ versus inferred structural elevation yields a correlation coefficient of 0.19 , which is not significant at the 0.95 probability level.

The lack of significant variation in structural state with inferred depth of crystallization or with inferred mode of crystallization (volcanic phenocryst versus volcanic matrix versus hypabyssal ring pluton versus subvolcanic massif) suggests that the K-feldspar throughout the Butler Hill Caldera has re-equilibrated subsequent to crystallization. Because microcline is the thermodynamically stable state for K-feldspar under ambient conditions, one might expect re-equilibration to highly ordered structures to be the norm for the exposed portions of ancient igneous complexes. However, in the absence of deuteric, hydrothermal, or metamorphic conditions, the driving force for the orthoclase-tomicrocline transition is very low (Brown \& Parsons 1989), and K-feldspar with intermediate to low structural order has been documented from a number of unaltered Precambrian igneous complexes (Martin \& Falster 1986, Schandl et al. 1986, Stevenson \& Martin 1988). Therefore, we interpret the homogeneity in structural state of the K-feldspar across the entire Butler Hill Caldera complex to be evidence for a pervasive alteration event. 

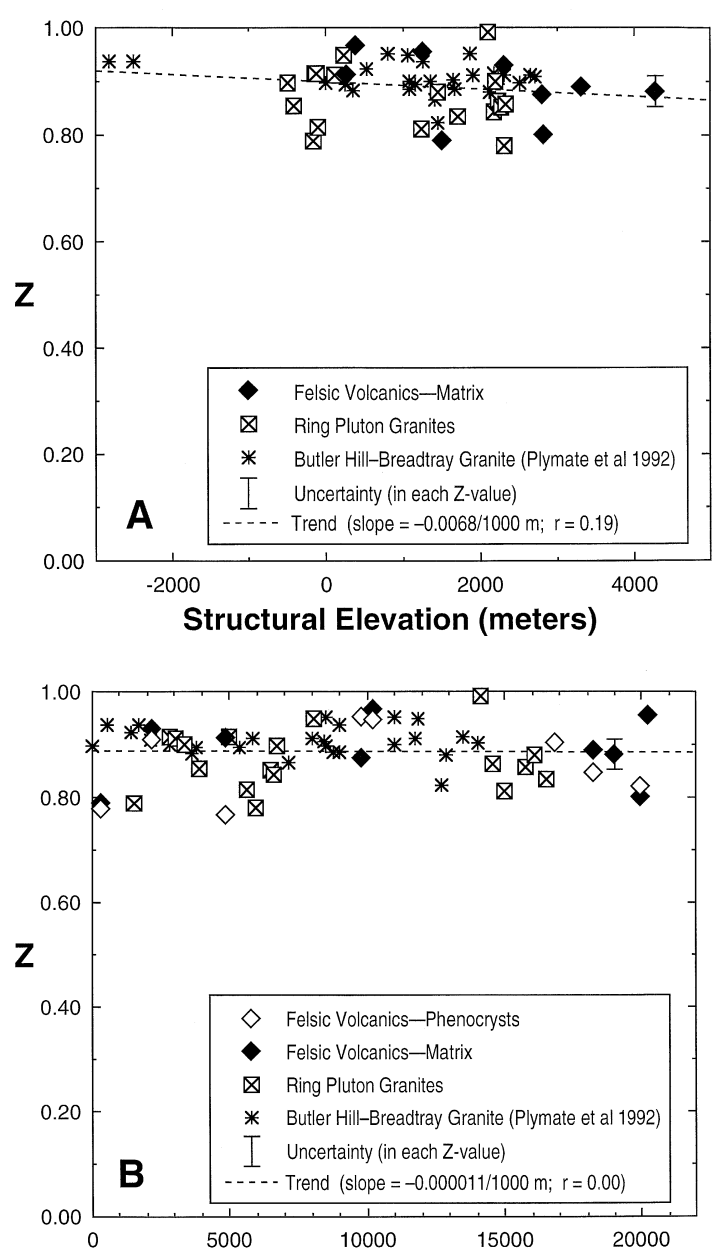

Horizontal Distance from Simms Mtn. Fault (meters)

Authors of numerous petrographic studies have documented extensive alteration of feldspars in the Butler Hill Caldera (Tolman \& Robertson 1969, Anderson 1970, Sides et al. 1981, Brown 1983, 1984, Lowell 1991). Our petrographic examination of the samples used in this study indicates that virtually all crystals of both K-feldspar and plagioclase are extensively altered. In some samples, the alteration products are sufficiently coarse-grained that individual crystals of muscovite and hematite can be identified, but in most samples, the alteration products appear primarily as a pervasive finegrained "clouding" of the feldspars. We ran the $\mathrm{X}$-ray-diffraction spectra for seven of our K-feldspar concentrates to $2^{\circ} 2 \theta$, and we detected peaks for illite or kaolinite (or both) in five of them. The detection of XRD peaks for phyllosilicates even in random-orientation powder mounts attests to the abundance of fine-grained alteration products in these rocks.

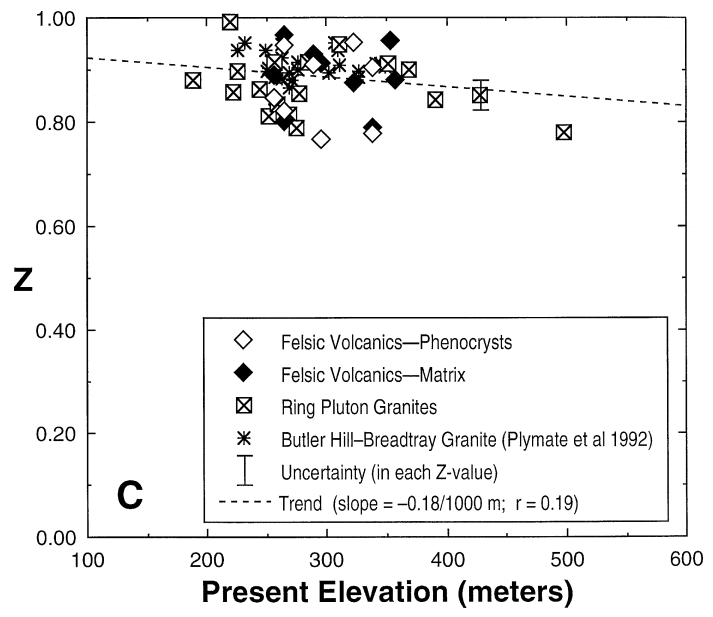

FIG. 4. Structural state of K-feldspar, as monitored by the parameter $Z$, versus (A) "structural elevation" as defined as perpendicular distance to a surface dipping $10^{\circ}, \mathrm{S} 68^{\circ} \mathrm{W}$, arbitrarily anchored at sample site F4 of Plymate et al. (1992), (B) horizontal distance from Simms Mountain Fault, and (C) present topographic elevation.

A number of processes and events have been proposed to account for alteration of rocks in the Butler Hill Caldera, and it seems likely that the homogenization of the K-feldspar structural state also resulted from one or more of these:

1. devitrification of the ash in the felsic volcanic units (Brown 1984).

2. liberation of deuteric fluids during crystallization of the subvolcanic massif, the Butler Hill - Breadtray Granite (Tolman \& Robertson 1969).

3. liberation of deuteric or hydrothermal fluids during the emplacement and crystallization of the ring plutons (Brown 1984, Lowell 1991).

4. alkaline magmatism at approximately $1.36 \mathrm{Ga}$ (Van Schmus et al. 1996), which produced two-mica "tin granites" and associated magmatic iron-ore deposits (Kisvarsanyi 1980, 1981, Kisvarsanyi \& Kisvarsanyi 1989).

5. emplacement of basaltic dikes and related mafic intrusive bodies. There appear to have been two episodes of mafic magmatism in the caldera, the first essentially contemporaneous with the end of the felsic igneous activity at $1.47 \pm 0.03 \mathrm{Ga}$, and the second at approximately $1.33 \mathrm{Ga}$ (Amos \& Desborough 1970, Honda et al. 1985, Rämö et al. 1994, Lowell \& Rämö 1999, Lowell \& Young 1999).

6. migration of fluids associated with development of the Simms Mountain Fault and other related northwest-striking transfer faults formed during the Late Proterozoic - Early Cambrian opening of the Reelfoot Rift (Clendenin et al. 1989, Lowell 1991). 
7. weathering of the Proterozoic rocks during subaerial exposure prior to deposition of the Upper Cambrian Lamotte Sandstone.

8. dolomitization of the Upper Cambrian Bonneterre Formation (Stein \& Kish 1991, Shelton et al. 1992).

9. formation of the "Mississippi-Valley-type" $\mathrm{Pb}$ $\mathrm{Zn}-\mathrm{Cu}$ sulfide ore deposits within the Upper Cambrian strata (Hagni 1989, Aleinikoff et al. 1993, Clendenin et al. 1994).

10. migration of fluids associated with reactivation of the Simms Mountain Fault and other related northwest-striking faults during the Middle to Late Paleozoic uplift of the Ozark Dome (Clendenin et al. 1989, Lowell 1991).

Of these ten events, the first two are inadequate to explain the uniformity in structural state of the K-feldspar throughout the entire Butler Hill Caldera because they preceded crystallization of one or more of the major rock units exposed within the complex. In particular, the presence of uniformly highly ordered K-feldspar in each of the hypabyssal ring plutons indicates that the homogenization of the K-feldspar structural state must have occurred subsequent to (or at least simultaneous with) the last major phase of the $1.47 \pm 0.03 \mathrm{Ga}$ magmatism. The third and fifth events listed, crystallization of the ring plutons and emplacement of the basaltic dikes, are unlikely candidates for explaining the widespread structural homogenization of K-feldspar because their effects should have been rather localized.

If modification of the K-feldspar structural state had been caused by fluids emanating from the Simms Mountain Fault and related northwest-trending faults (events \#6 and \#10 as listed above), one would expect lateral gradients with distance from those structures. Wenner $\&$ Taylor (1976) found that oxygen isotope ratios in most major igneous rock units exposed in the St. Francois Mountains have been reset by reaction with low-temperature $\left(<200^{\circ} \mathrm{C}\right)$ hydrothermal fluids, and Lowell \& Clendenin (1991) demonstrated that the extent of this isotopic disturbance varies proportionally with proximity to the Simms Mountain Fault and the parallel fault to the southwest, the Black Fault. Our data shows no corresponding variation with distance from these faults (Fig. 4B). We therefore conclude that the process responsible for structural homogenization of the $\mathrm{K}$-feldspar was an event more pervasive than fault-controlled migration of low-temperature hydrothermal fluids.

Modification of the K-feldspar in the Mesoproterozoic igneous rocks of the Butler Hill Caldera caused primarily by subaerial weathering prior to deposition of the Upper Cambrian Lamotte Sandstone (\#7) or by migration of fluids through the overlying Paleozoic sedimentary rocks (\#8 or \#9) should vary vertically with present topographic elevation. Sutton \& Maynard (1996) reported such a relationship for alteration in the Paleozoic strata in five cores drilled around the perim- eter of the St. Francois Mountains. However, K-feldspar structural state in the underlying igneous rocks shows no corresponding variation with present elevation (Fig. 4C). A linear regression of $Z$ versus present topographic elevation for our data, combined with the data of Plymate et al. (1992) [recalculated using the regression equations of Kroll \& Ribbe (1987)] yields a correlation coefficient of 0.19 , which is not significant at the 0.95 probability level. We therefore conclude that the process responsible for structural homogenization of the K-feldspar was other than, and more pervasive than, subaerial weathering or migration of fluids through the overlying sedimentary rocks.

We believe that the most likely cause of the homogenization of the K-feldspar structural state is late-stage alkaline magmatic activity (event \#4). By analyzing drill-core samples from throughout southeastern Missouri, Kisvarsanyi $(1980,1981)$ has determined that a significant fraction of the granite in the Mesoproterozoic St. Francois Terrane, particularly that portion of the terrane presently buried under Paleozoic sedimentary rocks, is alkali-rich "tin granite" formed by resurgent doming to create central plutons within most of the major caldera structures. The central pluton in the Taum Sauk Caldera, the Graniteville Granite, has been dated by $\mathrm{U}-\mathrm{Pb}$ zircon geochronology at approximately 1.36 Ga (Van Schmus et al. 1996). The Butler Hill Caldera differs from the Taum Sauk Caldera and most of the buried caldera structures in that its volcanic pile and comagmatic subvolcanic granite massif are of sufficient thickness that no resurgent central pluton is exposed or has been encountered in drilling. Evidence that such a late-stage alkaline central pluton exists at depth within the Butler Hill Caldera comes primarily from the various types of geochemical alteration of the 1.47 Ga rocks, which can be attributed to this later igneous activity, including emplacement of magmatic iron-ore bodies into the volcanic pile (Kisvarsanyi 1981, Kisvarsanyi \& Kisvarsanyi 1989).

Anderson (1970) and Brown (1983, 1984) documented extensive chemical alteration in the volcanic rocks of the St. Francois Mountains. By re-analyzing the data of Bickford et al. (1981), Cullers et al. (1981), and Pallesen et al. (1988), Lowell (1991) demonstrated that the major plutonic rock units exposed in the Butler Hill Caldera have undergone extensive subsolidus geochemical alteration, including alkali-exchange metasomatism. Bickford \& Mose (1975) found that Rb-Sr ages for many of the major rock units exposed in the St. Francois Mountains appear to be younger than the U$\mathrm{Pb}$ zircon ages for those same rock units by $0.1 \mathrm{Ga}$ or more. They attributed this discrepancy to a pervasive geochemical event that resulted in a systematic loss of Sr across the complex.

Lowell (1991) and Lowell \& Clendenin (1991) attributed the pervasive geochemical alteration within the Butler Hill Caldera to at least two separate episodes of 
metasomatism: (1) an initial high-temperature event involving convective circulation of meteoric water driven by heat from late-stage plutonic activity, and (2) a lowertemperature "postmagmatic thermotectonic event" associated with the Late Proterozoic development of the Reelfoot Rift. We believe that the structural homogenization of the K-feldspar throughout the Butler Hill Caldera is most likely correlated with the earlier of these two events, and we further believe that this event was most likely caused by the $1.36 \mathrm{Ga}$ alkaline magmatism.

$\mathrm{X}$-ray measurements of the unit-cell dimensions of an alkali feldspar allow calculation not only of its structural state, but also its composition. $\mathrm{N}_{\text {Or }}$, the mole fraction of the K-feldspar end-member, is very close to 1.00 for the alkali feldspar phase in each major rock unit exposed in the Butler Hill Caldera (Table 2 of this study, plus Table 2 of Plymate et al. (1992) for the Butler Hill - Breadtray Granite). For such K-rich compositions to result from subsolidus exsolution would require thermal equilibrium to be maintained to rather low temperature (probably 200 to $300^{\circ} \mathrm{C}$, depending on the pressure) (Martin 1974, Yund \& Tullis 1983). In turn, if thermal equilibrium had been maintained at such low temperature for even a moderately extended period of time, especially in the presence of metasomatic fluids, one would expect the alkali feldspar to have attained very nearly complete structural order $(Z \cong 1.00)$ (Brown \& Parsons 1989). The fact that the alkali feldspar throughout the Butler Hill Caldera shows high but not maximum structural order suggests that the structural state of these feldspars was homogenized by thermal annealing at a moderately high subsolidus temperature, and that the compositions were subsequently purified by lower-temperature hydrothermal/metasomatic alteration. Therefore, we contend that the homogenization of the structural state of the feldspars throughout the complex was caused primarily by heat from the $1.36 \mathrm{Ga}$ alkaline magmatism, and that the compositional purification reflects one or more subsequent, lower-temperature events.

\section{ACKNOWLEDGEMENTS}

We thank the U.S. National Science Foundation (Grant EAR-9218906) and Southwest Missouri State University for providing funding for the X-ray-diffraction system used in this study. We thank Mike Anderson and Ed Brown, U.S. Forest Service, for access to Stono Mountain, Robert F. Martin, McGill University, for providing the reference microcline sample used to confirm the accuracy of our experimental procedure, and Jennifer Rusher for preparing thin sections. We also gratefully acknowledge helpful suggestions from Achille Blasi, Vernon M. (Max) Brown, Warren Day, Gary R. Lowell, Robert F. Martin, Robert D. Schuster, Cheryl M. Seeger, and two anonymous reviewers.

\section{REFERENCES}

Aleinikoff, J.B., Walter, M., Kunk, M.J. \& Hearn, P.P., JR. (1993): Do ages of authigenic K-feldspar date the formation of Mississippi Valley-type $\mathrm{Pb}-\mathrm{Zn}$ deposits, central and southeastern United States?: Pb isotopic evidence. Geology 21, 73-76.

Amos, D.H. \& Desborough, G.A. (1970): Mafic intrusive rocks of Precambrian age in southeast Missouri. Missouri Division of Geology and Land Survey, Report of Investigations 47.

ANDERSON, R.E. (1970): Ash-flow tuffs of Precambrian age in southeast Missouri. Missouri Division of Geology and Land Survey, Report of Investigations 46.

Appleman, D.E. \& Evans, H.T., JR. (1973): Job 9214: Indexing and least-squares refinement of powder diffraction data. U.S. Geol. Surv. Comp. Contrib. 20 (U.S. Nat. Tech. Inf. Serv. Doc. PB216188).

Bevington, P.R. (1969): Data Reduction and Error Analysis for the Physical Sciences. McGraw-Hill, New York, N.Y.

BiCKFord, M.E., Lowell, G.R., Sides, J.R. \& Nusbaum, R.L. (1977): Inferred structural configuration of the St. Francois Mountains batholith, southeastern Missouri. Geol. Soc. Am., Abstr. Programs 9, 574-575.

\& Mose, D.G. (1975): Geochronology of Precambrian rocks in the St. Francois Mountains, southeastern Missouri. Geol. Soc. Am., Spec. Pap. 165.

SIDES, J.R. \& CuLLERS, R.L. (1981): Chemical evolution of magmas in the Proterozoic terrane of the St. Francois Mountains, southeastern Missouri. 1. Field, petrographic, and major element data. J. Geophys. Res. B86, 10365-10386.

Brown, V.M. (1983): The Precambrian Volcanic Stratigraphy and Petrology of the Des Arc NE 7 1/2 Minute Quadrangle, South Central St. Francois Mountains, Missouri. Ph.D. dissertation, Univ. Missouri-Rolla, Rolla, Missouri.

(1984): Chemical signatures of hydrothermally altered Precambrian ash-flow tuffs, St. Francois Mountains, southeast Missouri. Geol. Soc. Am., Abstr. Programs 16, 457.

BROWN, W.L. \& PARSONS, I. (1989): Alkali feldspars: ordering rates, phase transformations and behaviour diagrams for igneous rocks. Mineral. Mag. 53, 25-42.

Clendenin, C.W., Niewendorp, C.A., Duane, M.J. \& Lowell, G.R. (1994): The paleohydrology of southeast Missouri Mississippi Valley-type deposits: interplay of faults, fluids, and adjoining lithologies. Econ. Geol. 89, 322-332.

\& Lowell, G.R. (1989): Reinterpretation of faulting in southeast Missouri. Geology 17, 217 220. 
Cullers, R.L., Koch, R.J. \& BickFord, M.E. (1981): Chemical evolution of magmas in the Proterozoic terrane of the St. Francois Mountains, southeastern Missouri. 2. Trace element data. J. Geophys. Res. B86, 10388-10401.

HAGNI, R.D. (1989): The southeast Missouri lead district: a review. In Mississippi Valley-Type Mineralization of the Viburnum Trend, Missouri (R.D. Hagni \& R.M. Coveney, Jr., eds.). Soc. Econ. Geol., Guidebook Ser. 5, 12-57.

Honda, M., Sylvester, P.J., Podosek, F.A. \& Schulz, K.J. (1985): ${ }^{40} \mathrm{Ar} /{ }^{39} \mathrm{Ar}$ geochronology of mafic rocks from the granite-rhyolite terrane of southeastern Missouri. Precamb. Res. 27, 301-306.

Hovis, G.L. (1986): Behavior of alkali feldspars: crystallographic properties and characterization of composition and Al-Si distribution. Am. Mineral. 71, 869-890.

Kisvarsanyi, E.B. (1980): Granitic ring complexes and Precambrian hot-spot activity in the St. Francois terrane, midcontinent region, United States. Geology 8, 43-47.

(1981): Geology of the Precambrian St. Francois terrane, southeastern Missouri. Missouri Division of Geology and Land Survey, Report of Investigations 64.

(1990): General features of the St. Francois and Spavinaw granite-rhyolite terranes and the Precambrian metallogenic region of southeast Missouri. In The Midcontinent of the United States - Permissive Terrane for an Olympic Dam-Type Deposit? (W.P. Pratt \& P.K. Sims, eds.). U.S. Geol. Surv., Bull. 1932, 48-57.

Hebrank, A.W. \& Ryan, R.F. (1981): Guidebook to the geology and ore deposits of the St. Francois Mountains, Missouri. Missouri Division of Geology and Land Survey, Report of Investigations 67.

Kisvarsanyi, G. \& Kisvarsanyi, E.B. (1989): Precambrian geology and ore deposits of the southeast Missouri iron metallogenic province. In "Olympic Dam-Type" Deposits and Geology of Middle Proterozoic Rocks in the St. Francois Mountains Terrane, Missouri (V.M. Brown, E.B. Kisvarsanyi \& R.D. Hagni, eds.). Soc. Econ. Geol., Guidebook Ser. 4, 1-40.

Kroll, H. \& RibBE, P.H. (1983): Lattice parameters, composition, and $\mathrm{Al}, \mathrm{Si}$ order in alkali feldspars. In Feldspar Mineralogy (2nd edition; P.H. Ribbe, ed.). Rev. Mineral. 2, $57-$ 99.

\& (1987): Determining (Al,Si) distribution and strain in alkali feldspars using lattice parameters and diffraction-peak positions: a review. Am. Mineral. 72, 491-506.

Lowell, G.R. (1991): The Butler Hill Caldera: a midProterozoic ignimbrite-granite complex. Precamb. Res. 51, 245-263.

\& Clendenin, C.W. (1991): Fault control on lowtemperature alteration in the St. Francois highlands. Louis Unfer, Jr. Conference on the Geology of the Mid-Missis- sippi Valley - Extended Abstracts. Missouri Department of Natural Resources, Spec. Publ. 8, 65-68.

\& RÄмÖ, O.T. (1999): Petrology and geochemistry of the Shepard Mountain Gabbro: implications for basalt genesis at $1.33 \mathrm{Ga}$ in southeast Missouri. Geol. Soc. Am., Abstr. Programs 31(5), A-32.

\& Young, G.J. (1999): Interaction between coeval mafic and felsic melts in the St. Francois Terrane of Missouri, USA. Precamb. Res. 95, 69-88.

Lyon, A.J. (1970): Dealing with Data. Pergamon Press, New York, N.Y.

MARTin, R.F. (1974): Controls of ordering and subsolidus phase relations in the alkali feldspars. In The Feldspars (W.S. MacKenzie \& J. Zussman, eds.). Manchester University Press, Manchester, U.K. (313-336).

\& FAlSter, A.U. (1986): Proterozoic sanidine and microcline in pegmatite, Wausau complex, Wisconsin. Can. Mineral. 24, 709-716.

MeYer, S.L. (1975): Data Analysis for Scientists and Engineers. John Wiley \& Sons, New York, N.Y.

Pallesen, T.J., NABeleK, P.I., \& Glascock, M.D. (1988): Compositional and textural zonation in the Silvermine Granite, Missouri: the role of liquid fractionation and Kmetasomatism in the formation of a W-Sn deposit. In North American Conference on Tectonic Control of Ore Deposits and the Vertical and Horizontal Extent of Ore Systems, Proceedings Volume (G. Kisvarsanyi \& S.K. Grant, eds.), Univ. Missouri - Rolla, Rolla, Missouri (346-357).

Plymate, T.G., Daniel, C.G. \& CAVAleRi, M.E. (1992): Structural state of the K-feldspar in the Butler Hill - Breadtray Granite, St. Francois Mountains, southeastern Missouri. Can. Mineral. 30, 367-376.

Pratt, W.P., Anderson, R.E., Berry, A.W., Jr., Bickford, M.E., Kisvarsanyi, E.B. \& Sides, J.R. (1979): Geologic map of exposed Precambrian rocks, Rolla $1^{\circ} \times 2^{\circ}$ quadrangle, Missouri. U.S. Geol. Surv., Misc. Investigations Ser., Map I-1161.

RÄmÖ, O.T., Boyd, W.W., VAASJOKi, M, CAMERON, R.L. \& RYCKMAN, D.A. (1994): $1.3 \mathrm{Ga}$ magmatism of the St Francois Mountains of SE Missouri: implications for mantle composition beneath mid-continental USA. Mineral. Mag. 58A, 754-755.

RiBBE, P.H., ed. (1983): Feldspar Mineralogy (2nd edition). Rev. Mineral. 2.

Schand, E.S., Martin, R.F. \& Stevenson, J.S. (1986): Feldspar mineralogy of the Sudbury igneous complex and the Onaping Formation, Sudbury, Ontario. Can. Mineral. 24, 747-759.

Shelton, K.L., Bauer, R.M. \& GregG, J.M. (1992): Fluidinclusion studies of regionally extensive epigenetic dolomites, Bonneterre Dolomite (Cambrian), southeast 
Missouri: evidence of multiple fluids during dolomitization and lead-zinc mineralization. Geol. Soc. Am., Bull. 104, 675-683.

SIDES, J.R. (1980): Emplacement of the Butler Hill Granite, a shallow pluton within the St. Francois Mountains batholith, southeastern Missouri. Geol. Soc. Am., Bull. 91, 535-540.

BiCKFord, M.E., SHUSTER, R.D. \& Nusbaum, R.L. (1981): Calderas in the Precambrian terrane of the St. Francois Mountains, southeastern Missouri. J. Geophys. Res. B86, 10349-10364.

SteIN, H.J. \& KISH, S.A. (1991): The significance of Rb-Sr glauconite ages, Bonneterre Formation, Missouri: late Devonian - early Mississippian brine migration in the midcontinent. J. Geol. 99, 468-481.

Stevenson, R.K. \& Martin, R.F. (1988): Amazonitic K-feldspar in granodiorite at Portman Lake, Northwest Territories: indications of low $f\left(\mathrm{O}_{2}\right)$, low $f\left(\mathrm{~S}_{2}\right)$, and rapid uplift. Can. Mineral. 26, 1037-1048.

SutTON, S.J. \& MAYNARD, J.B. (1996): Basement unconformity control on alteration, St. Francois Mountains, SE Missouri. J. Geol. 104, 55-70.

Tolman, C.F. \& RoberTson, F. (1969): Exposed Precambrian rocks in southeast Missouri. Missouri Division of Geology and Land Survey, Report of Investigations 47.

Van Schmus, W.R., Bickford, M.E., Anderson, J.L., BENDER, E.E., ANDERSON, R.R., BAUER, P.W., ROBERTSON, J.M., Bowring, S.A., Condie, K.C., Denison, R.E., GIL-
Bert, M.C., Grambling, J.A., Mawer, C.K., Shearer, C.K., Hinze, W.J., Karlstrom, K.E., Kisvarsanyi, E.B., LidiaK, E.G., ReEd, J.C., JR., Sims, P.K., Tweto, O., SilVer, L.T., Treves, S.B., Williams, M.L. \& Wooden, J.L. (1993): Transcontinental Proterozoic provinces. In Precambrian: Conterminous U.S. (J.C. Reed, Jr., M.E. Bickford, R.S. Houston, P.K. Link, D.W. Rankin, P.K. Sims \& W.R. van Schmus, eds.). Geol. Soc. Am., Geology of North America C-2, 171-334.

WenNER, D.B. \& TAYLOR, H.P., JR. (1976): Oxygen and hydrogen isotope studies of a Precambrian granite-rhyolite terrane, St. Francois Mountains, southeastern Missouri. Geol. Soc. Am., Bull. 87, 1587-1598.

WRIGHT, T.L. (1968): X-ray and optical study of alkali feldspar. II. An X-ray method for determining the composition and structural state from measurement of $2 \theta$ values for three reflections. Am. Mineral. 53, 88-104.

\& STEWART, D.B. (1968): X-ray and optical study of alkali feldspar. I. Determination of composition and structural state from refined unit-cell parameters and $2 \mathrm{~V}$. Am. Mineral. 53, 38-87.

Yund, R.A. \& TulLis, J. (1983): Subsolidus phase relations in the alkali feldspars with emphasis on coherent phases. In Feldspar Mineralogy (2nd. edition; P.H. Ribbe, ed.). Rev. Mineral. 2, 141-176.

Received February 9, 2000, revised manuscript accepted January 1, 2001. 